Max-Planck-Institut für demografische Forschung

Max Planck Institute for Demographic Research

Konrad-Zuse-Strasse 1 - D-18057 Rostock - GERMANY

Tel +49 (0) 3812081 - 0; Fax +49 (0) 3812081 - 202;

http://www.demogr.mpg.de

MPIDR WORKING PAPER WP 2011-010

JUNE 2011

\title{
Economic Conditions of Stepfamilies from a Cross-National Perspective
}

\author{
Michaela Kreyenfeld (kreyenfeld@demogr.mpg.de) \\ Valerie Martin
}

(c) Copyright is held by the authors.

Working papers of the Max Planck Institute for Demographic Research receive only limited review. Views or opinions expressed in working papers are attributable to the authors and do not necessarily reflect those of the Institute. 


\title{
Economic Conditions of Stepfamilies from a Cross-National Perspective
}

\author{
Michaela Kreyenfeld (Max Planck Institute for Demographic Research, Rostock) \\ Valerie Martin (German Youth Institute, Munich) ${ }^{1}$
}

\begin{abstract}
This paper investigates the economic conditions of stepfamilies in Germany, the Russian Federation and France using data from the first wave of the Generations and Gender Survey (GGS). The analysis shows that stepfamilies more often report economic hardship than nuclear families in France and western Germany. Socio-demographic differences between family types — particularly the fact that stepfamilies tend to be larger families — explain the differences in economic well-being between families in France. For western Germany, differences between nuclear and stepfamilies remain after controlling for socio-economic composition of different family types. For the Russian Federation and eastern Germany, we do not find any statistically significant differences in economic well-being between stepfamilies and nuclear families. The major dividing line for these regions runs between single parents and other types of families.
\end{abstract}

Keywords: Stepfamilies, family changes, western Germany, eastern Germany, Russian Federation, France

1 Since this work is the share of two the authors are presented in an alphabetical order 


\title{
Die ökonomische Situation von Stieffamilien im internationalen \\ Vergleich
}

\author{
Michaela Kreyenfeld (Max-Planck-Institut für demografische Forschung, Rostock) \\ Valerie Martin (Deutsches Jugendinstitut, München)
}

\section{Zusammenfassung}

In diesem Beitrag werden die Daten der ersten Welle des Generations and Gender Survey (GGS) verwendet, um die die ökonomische Situation von Stieffamilien in Deutschland, der russischen Föderation und Frankreich zu untersuchen. Die Ergebnisse zeigen, dass Stieffamilien in Frankreich und in Westdeutschland häufiger ökonomischen Schwierigkeiten ausgesetzt sind als Kernfamilien. Soziodemographische Unterschiede zwischen den unterschiedlichen Familientypen, insbesondere die Tatsache, dass Stieffamilien größere Familien mit mehreren Kindern sind, können die Unterschiede in der Einschätzung der ökonomischen Situation in Frankreich erklären. Für Westdeutschland bleiben jedoch auch nach Kontrolle der soziodemographischen Merkmale die Unterschiede zwischen den Familientypen bestehen. Für die russische Föderation und für Ostdeutschland lassen sich keine signifikanten Unterschiede in der Einschätzung der ökonomischen Situation zwischen Stieffamilien und Kernfamilien aufzeigen. Die zentrale Trennlinie verläuft hier zwischen Alleinerziehenden und anderen Familienformen.

Schlagwörter: Stieffamilie, familialer Wandel, Westdeutschland, Ostdeutschland, Russische Föderation, Frankreich 


\section{Introduction}

It is commonly understood by family sociologists that the nuclear family — defined as a married couple with their biological children — is merely an ideological construct, rather than an exclusive family model (Coontz 2000; Nave-Herz 1998). However, recent changes in family behaviour suggest that the nuclear family is retreating more rapidly than ever before. Increasing separation risks challenge the dominant position of the nuclear family, as other types of families, such as stepfamilies, are becoming more prevalent. It is, however, not just the increase in numbers that makes it appealing to study stepfamilies. They are in many respects distinct and "novel" family forms. While stepfamilies were historically mainly formed through remarriages after widowhood (Juby 2003-2004: 5), they are today overwhelmingly formed after separation. Hence, the stepparent is not replacing the biological parent, but is instead added to the existing family. The consequence is an increasing complexity of stepfamilies and extensive stepfamily networks.

The first quantitative studies that tried to assess the prevalence of stepfamilies were conducted for the U.S. In these earlier studies, stepfamilies were mainly defined as marital unions that had evolved through re-marriages (e.g. Cherlin 1978; White and Booth 1985; Glick 1989). However, research for European countries, and more recent research for the U.S. and Canada, have integrated cohabitation into the definition of what constitutes a stepfamily (Cherlin and Furstenberg 1994; Desrosiers et al. 1995; Bumpass et al. 1995). The most common understanding now is that a stepfamily is composed of a marital or non-marital couple who coreside with children who originate from a prior partnership (Bumpass et al. 1995; Martin and Le Bourdais 2008). It is also acknowledged that "living apart together" arrangements can qualify as a stepfamily, as non-coresiding partners might form a strong bond with the child of a "serious romantic partner" (Bien et al. 2002: 11; Stewart 2007: 2). However, these family 
forms have so far seldom been addressed in empirical investigations of stepfamilies (an exception is a study by Feldhaus and Huinink 2011). Unfortunately, we are not able to address this issue in this paper either and follow the classical definition, which defines a stepfamily as a couple who lives with children from a prior partnership.

The main goal of this paper is to study the socio-economic well-being of stepfamilies in France, the Russian Federation and Germany based on recent data from the Generations and Gender Survey (GGS). We have selected these three countries not only because they cover a large fraction of the population in Europe, but also because these countries represent different welfare regimes with contrasting demographic behaviour. Social policies may influence stepfamilies in several ways. Firstly, they influence the trajectories that lead to stepfamily membership as they define the incentives to choose a particular family form. Secondly, social policies define the well-being of stepfamilies because maintenance regulations towards children and ex-spouses have a direct bearing on the economic performance of stepfamilies. We investigate how stepfamilies perform in these countries compared to nuclear families on the one hand and lone parents on the other hand. We ask whether the special characteristics of stepfamilies — including the fact that they tend to be larger families — could explain why this group experiences greater economic hardship than other family types. The operational definition of economic condition is whether the respondent evaluates his or her own economic situation as being difficult. 


\section{Trajectories into stepfamily membership}

Becoming a member of a stepfamily involves a series of life-course transitions. For the biological parent, these transitions include the birth of a child, the separation from the biological father (or mother) of the child and the entrance into a new coresidential union with a new partner. For the stepparent, the transition involves (at a minimum) the formation of a household with a new family and the entry into the parental role, possibly for the first time in his or her life. Meanwhile, the child mostly has to undergo separation of the biological parent, and accept the entrance of a stepparent into the household. A new child might be born into a stepfamily, which eventually transforms the family into a "blended family". Investigating the prevalence and economic conditions of stepfamilies requires an understanding of the lifecourse trajectory that leads to becoming a member of a stepfamily (Bumpass et al. 1995; Prskawetz et al. 2003).

From the $16^{\text {th }}$ to the $19^{\text {th }}$ centuries, the formation of a stepfamily was usually preceded by the death of a partner. Remarriages after the death of a partner were very common, and were often economically necessary to sustain the household (Teubner 2002a). Due to high maternal death rates, it was often the widower who remarried quickly in order to keep the family system intact. Thus, stepmother families, in which the biological mother was replaced by a stepmother, were the main types of stepfamilies at that period of time. With the decline of mortality rates during the first demographic transition, the importance of stepfamilies decreased continuously. In the aftermath of World War II, separation, divorce and widowhood increased again (Saint-Jacques 1998), but the "golden age of marriage" (Festy 1980) that followed in the subsequent years created conditions that led to a historic low in the number of stepfamilies. 
The increase in divorce and separation rates since the 1960s has ushered in a new era in which stepfamilies have become an integral part of the family of contemporary Europe. Whereas in the past stepfamilies were formed through the death of a married partner, stepfamilies are today commonly formed after a separation or divorce from a partner. Thus, the paths that lead to the formation of a stepfamily have become more diverse. It is usually divorce, the breakdown of a cohabiting union or the termination of a more loose relationship, such as a living apart together arrangement, that lead to the formation of a stepfamily. Furthermore, unlike in the past, today children overwhelmingly remain with the biological mother after separation, which inevitably results in a greater number of stepfather families (VilleneuveGokalp 2000).

\section{Stepfamilies and family change}

Although divorce and separation rates have increased across Europe since the 1960s, marked differences in demographic behaviour have remained. Eastern Germany, western Germany, the Russian Federation and France differ greatly in terms of family behaviour, and, thus, also in the paths typically followed in these countries in forming a stepfamily. A salient characteristic of family behaviour of the western German population is that a high percentage of men and women continue to get married prior to having children (Kreyenfeld et al. 2011). Non-marital births have increased since the 1990s, and particularly since 1998, when the Kindschaftsrecht was reformed, and unmarried parents were finally granted joined custody. However, marriage is still an important transition for many couples before they have a first child. From this it follows that the group "at risk of forming a stepfamily" is mainly composed of divorcees in western Germany. 
The eastern German pattern differs considerably from the western German one, as unmarried parenthood is at record high levels in the East. The same can be said of the French "demographic regime" (see Table 1). Unmarried mothers are overwhelmingly women who co-reside with a partner in both France and eastern Germany (Konietzka and Kreyenfeld 2002; Köppen 2011). As such, the breakdown of a cohabiting union should be a frequent pathway to forming a stepfamily in these two regions. The fact that cohabiting unions are less stable than marriages might be an additional factor which would explain why there is a large share of unmarried women in the pool of those "at risk of forming a stepfamily" (MarcilGratton et al. 2000; Juby et al. 2001).

In the Russian Federation, cohabitation is still rare, and early marriage and childbearing are almost universal (Perelli-Harris and Gerber 2010). Unfortunately, we do not have access to recent period divorce rates for the Russian Federation, but we do know that Russian divorce rates were among the highest in Europe in 1990 (Table 1). Studies based on micro-level data support the assumption that divorce intensities continued to increase in Russia thereafter (Muszynska 2006). A characteristic of the Russian regime is also the very low age at childbearing, which suggests that Russian women are not only more likely to be (prior) divorcees when they enter a stepfamily, but that they are also likely to be substantially younger than women in France or Germany. Additionally, as the country is well known for its high male mortality rates (Andrev et al. 2009; Leon et al. 2009), the Russian Federation might be one of the few European countries where the death of the spouse is still a frequent transition in the trajectory of becoming a stepfamily. 
Table 1: Demographic indicators for France, the Russian Federation, eastern and western Germany 1960-2008

\begin{tabular}{|lrrrrrr|}
\hline & 1960 & 1970 & 1980 & 1990 & 2000 & 2008 \\
\hline Share of non-marital births & & & & & & \\
France & 6.1 & 6.8 & 11.4 & 30.1 & 42.6 & 51.6 \\
Western Germany & 6.3 & 5.5 & 7.6 & 10.5 & 18.6 & 25.8 \\
Eastern Germany & 11.6 & 13.3 & 22.8 & 35.0 & 51.5 & 60.7 \\
Russian Federation & 13.1 & 10.6 & 10.8 & 14.6 & 28.0 & $28.0^{\mathrm{ii})}$ \\
& & & & & & \\
Total divorce rate & & & & & & \\
France & 0.10 & 0.12 & 0.22 & 0.32 & 0.38 & $0.47 \mathrm{i})$ \\
Western Germany & - & 0.15 & 0.23 & 0.31 & $0.42^{\mathrm{a})}$ & $0.43^{\mathrm{aji}}$ \\
Eastern Germany & 0.16 & 0.19 & 0.32 & 0.24 & $0.34^{\mathrm{b})}$ & $0.37^{\mathrm{bji}}$ \\
Russian Federation & 0.17 & 0.34 & 0.42 & 0.40 & -- & -- \\
& & & & & & \\
Mean age at childbirth & & & & & & \\
France & & & & & & \\
Western Germany & 27.6 & 27.2 & 26.8 & 28.3 & 29.4 & 29.9 \\
Eastern Germany & 27.9 & 26.9 & 27.1 & $28.3^{\mathrm{c})}$ & $28.9^{\mathrm{c})}$ & $30.2^{\mathrm{c})}$ \\
Russian Federation & 26.4 & 25.4 & 24.5 & $25.1^{\mathrm{c})}$ & $27.6^{\mathrm{c})}$ & $29.1^{\mathrm{c})}$ \\
\hline & 28.2 & 26.9 & 25.7 & 25.3 & 25.8 & 27.2 \\
\hline
\end{tabular}

Notes: ${ }^{\text {a) }}$ with East Berlin; ${ }^{\text {b) }}$ without East Berlin ${ }^{\text {c) }}$ without Berlin; ${ }^{\text {i) }} 2006{ }^{\text {ii) }} 2007$

Sources: Council of Europe (2005); Eurostat (2011); Dorbritz (2007); Statistisches Bundesamt (2001); HFD (2011); Generations and Gender Programme (2011)

\section{Social policies and entrance into stepfamily membership}

Beyond these pure demographics, the social policy context should shape the formation of a stepfamily. Welfare state institutions are largely assumed to govern maternal and paternal employment patterns, and, in doing so, to define the prevalent earner model in a society (Esping-Andersen 1999; 2009). Social policies, however, also provide incentives to get married or to cohabit (Gauthier 2007: 26; Perelli-Harris and Sanchez-Gassen 2011), and thus create incentives to leave singlehood. As children overwhelmingly stay with their mothers 
after separation, policies that influence the well-being of divorced and single women should be most significant in explaining stepfamily formation. If lone mothers experience economic difficulties because they are unable to support their children, the pressure to enter into a stepfamily arrangement might be higher than in countries where single and divorced mothers can sustain a "livelihood of their own" (Orloff 1993: 311; Orloff 2009: 327).

Comparing the Russian Federation, France and Germany, we must conclude that the economic pressure to exit single motherhood is probably highest in the Russian Federation, where social support to single mothers was heavily curtailed after the demise of the communist system (Zabel 2008). Furthermore, public day care centers were shut down (Pascall and Manning 2000). The combination of these factors have produced a situation that leaves single mothers at exceptionally high poverty risk (Kanji 2004). Additionally, the extremely tight housing situation has forced many single mothers to live in extended kin household structures, either with parents or other relatives (Lokshin et al. 2000). Judging from the high re-marriage rates that have been reported for the Russian Federation (Spielauer et al. 2007), it seems plausible that both aspects taken together, economic strains and the housing situation, have created strong incentives for single mothers to enter a new relationship after separation, divorce or the death of a partner.

In France and Germany, as well, single mothers are at high risk of poverty (Bradshaw et al. 2006). However, the situation is still markedly different from that of Russia, as the general economic situation is substantially more advantageous in France and Germany. For France, it could also be argued that the welfare state enables women's autonomy, as it is geared towards the integration of women into the labour market (Lewis 1992: 165; Martin 1995). From this it follows that the economic pressure to leave single parenthood is less severe than it is in the Russian Federation. The same might be said about eastern Germany, where the wide availability of public day care enables women to be employed after having a child. 
In western Germany, a single mother's chances of being economically self-sustaining are generally seen as being rather limited. Because it is a "male breadwinner regime", the absence of a husband is usually considered a social risk factor (Ostner 1995). The incompatibility of work and employment could create economic pressure for single mothers to re-partner in order to avoid transfer dependency. However, there are also legal forces, such as maintenance payments, that could work in the opposite direction. Germany appears to differ from the other countries in this respect as maintenance payments to the care-giving ex-spouse were quite liberally granted until the reform of the alimony law in 2008. Until then, the parent who cared for a child could claim maintenance payments (Betreuungsunterhalt) until the child reached age eight, and was only expected to work part-time if the child was between ages eight and 14. However, the income of a new residential partner could be considered in the assessment of the maintenance payments of the ex-partner; upon re-marriage the payment was suspended completely. These regulations might have discouraged some people (or rather some women who were the main recipient of these payments) from getting married or forming a nonmarital union with a new partner, and thus entering a stepfamily. The legal regulations have been the same for both parts of Germany since unification. However, the Betreuungsunterhalt is probably not a relevant factor for explaining re-partnering behaviour in the East because eastern Germans marry less frequently, and maintenance regulations therefore do not apply to them to the same degree. ${ }^{2}$ Further, eastern German women often do not become eligible for maintenance claims because they either work themselves, or because the income of the expartner is so low that it barely suffices for paying child support.

2 It is in principle possible to claim maintenance (Betreuungsunterhalt) from the ex-partner of a nonmarital union. However, maintenance payments are restricted to the period until the child reaches age three. In 2008, the ability of divorced persons to claim maintenance has been curtailed, so that regulations for non-marital and marital unions have become more similar. As the data from the first wave of the GGS refer to the time before the reform, we do not discuss the new regulations in detail. 


\section{Stepfamilies: A selective population?}

When studying the economic well-being of stepfamilies, it is also necessary to consider that stepfamilies are a select group of families. In particular, they are often larger families because couples have a tendency to cement their partnership by having common children. This "union commitment" explains why the number of children is higher in step- than in nuclear families (Thomson et al. 2000; Buber and Prskawetz 2002; Prskawetz et al. 2003; Vikat et al. 2004; Henz and Thomson 2005; Holland and Thomson 2011).

Given that economic pressures increase with the number of children, stepfamilies should experience economic difficulties more often than nuclear families (Teubner 2002b). The fact that a portion of the household income hinges on the alimony payments of the ex-partner is also a distinctive aspect of stepfamilies, and might be another source of economic distress among stepfamilies.

However, stepfamilies might also differ in terms of other socio-economic characteristics, particularly if there is a social gradient entrenched in the trajectories that lead to becoming a stepfamily. If, for example, lone parenthood is more common among the less educated, we could expect to also find a social gradient by family type, assuming that lone parenthood is common in the trajectory to forming a stepfamily. However, becoming a stepparent also depends on the chances to re-partner, and unfortunately, there are only few studies on this topic available. Jaschinski (in this volume) analysed data from the German GGS and investigates how female education affects re-partnering behaviour. She argues that highly educated women should be less likely to re-partner as they are more economically independent than their less educated counterparts. However, she also acknowledges that highly educated women might be more advantaged on the partner market which increases their chances to enter into a new partnership. Empirical evidence is given for the latter presumption which shows that highly educated women experience elevated re-partnering 
rates. Similar findings have been reported by Wu and Schimmele (2002) for Canada. From these studies, it would follow that highly educated women are more likely to form a stepfamily. However, we also know that highly educated women are less likely to become a lone mother in Germany, France and the Russian Federation, as this is the case in most other parts of Europe (Perelli-Harris 2010). In essence, it is difficult to tell how the different transitions that lead to becoming a member of a stepfamily cumulate over the life course. Even if we knew that a negative social gradient existed in separation risks, we could not necessarily assume that we would find the same gradient in stepfamilies if the social gradient in re-partnering risks runs in the opposite direction. As such, it seems difficult to establish a priori whether we would find a negative or positive social gradient in stepfamily membership.

\section{Summary and research hypotheses}

In sum, the demographic regimes in eastern Germany, western Germany, France and the Russian Federation differ considerably. In light of these differences, we assume that the trajectories that lead to forming a stepfamily vary in the regions that we consider here. For the Russian Federation, we expect to find a high prevalence of stepfamilies due to the unusually high divorce rates in this country, and also because economic pressures might lead Russian women to try to re-partner after the breakdown of a union. We also anticipate that, in the Russian Federation, the share of women who enter a stepfamily after the death of partner will be shown to be higher than in other countries because of the high Russian mortality rates. For France and eastern Germany, we anticipate that the breakdown of a non-marital union will be found to be the standard track prior to entering a stepfamily while it is the dissolution of a marital union in western Germany.

Although we can make firm statements regarding the trajectories that lead into stepfamily membership, it is more difficult to provide concrete hypotheses regarding the economic 
conditions of stepfamilies. Because they are larger families, they require more housing space and economic resources and we may therefore assume that they are more prone to suffer economic hardship. Stepfamilies may also experience greater economic difficulties because the socio-economic composition of this type of family differs from that of other families. However, stepfamily membership can involve a series of life-course transitions. How the social gradient, which is entrenched in these transitions, will eventually add up over the life course is difficult to determine in advance, and must be explored using the given data.

\section{Data and sample}

\subsection{Data source: First wave of the GGS}

In the following, we use data from the first wave of the Generations and Gender Survey $(\mathrm{GGS})^{3}$ to study (a) the prevalence of stepfamilies, (b) the trajectories that lead to stepfamily membership (c) and the economic well-being of stepfamilies.

The GGS is an ideal data set for investigating the topic of stepfamilies as it contains detailed information about the relationship of the respondent to his or her children as well as to the children of the respondent's coresident partner. In a "household grid", the position of the respondent to each household member is assessed. The grid has the following categories: biological child with the current partner or spouse, biological child with a former partner or spouse, stepchild, adopted child, foster child, biological or adopted child. Additionally, the

3 The data for Germany (survey year 2005, version 2.0) and France (survey year 2005, version 1.7) have been made available by the United Nations (http://www.ggp-i.org/). The Russian data (survey year 2004) has been made available by the Max Planck Institute for Demographic Research. We used here a version that contained a cleaned educational variable. The cleaning has been done by Aiva Jasilioniene and Evgeny Andreev. 
respondent is asked to name the number of non-resident children, to give the relationship status for each child (biological, adopted or foster) and to provide information about whether the child is the biological child of the current spouse. In a separate section of the questionnaire, information on the children of the current partner is collected.

However, there are also some pitfalls related to this data set. The drawback of the Russian GGS is that non-response is rather high, particularly in the urban areas of Saint Petersburg and Moscow, where the response rate only reached 15 percent (Kosolapov and Zakharov 2005). Therefore, the Russian GGS is biased to some extent as it does not include sufficient respondents from these two urban areas of the Russian Federation. In the multivariate analysis, we account for this by controlling for whether the interview was conducted in Saint Petersburg or Moscow. There is also a problem related to the German data. External validation of the fertility and partnership histories has shown that the fertility and marriage rates of the younger cohorts are rather high, while they are much too low for the older cohorts. As a result, cohort marriage and fertility trends based on the German GGS do not follow the time trend suggested by vital statistics (Naderi et al. 2009; Kreyenfeld et al. 2010). The bias is particularly strong if we look at childlessness or try to generate estimates of ever-married men and women for the cohorts born before 1950. It has been assumed that the bias might relate to problems in the modules that collect information on past partnerships and on children who no longer live in the household of the respondent (Kreyenfeld et al. 2010). As the following analysis is restricted to young respondents who live with their children in the same household, we assume that the bias does not affect our investigation of the prevalence and economic conditions of stepfamilies. 


\subsection{Sample and definition}

This investigation is limited to women and men who have children ages 18 and younger with whom they coreside. We follow here the age definition used by prior studies (Teubner 2002a; Steinbach 2008). We distinguish between (a) respondents in nuclear families, (b) respondents in stepfamilies and (c) single parents.

Respondents who live in a nuclear family are defined as men and women who coreside with their marital or non-marital partner, and who only have common children who coreside with the parents. A respondent is assumed to live in a stepfamily if he or she lives in a marital or non-marital union and coresides with at least one child from a prior partnership. Single parents are respondents who do not live with a partner, but with biological children. The definition we adhere to follows the narrow principle of coresidence. This means that we do not consider partnerships if they do not have any children with whom they coreside. ${ }^{4}$ As such, childless respondents, non-residential fathers (and mothers) and parents whose children already have all left parental home are not part of this investigation. It should also be noted that we ignore extended family structures. We define family type only by the relationship to the coresident partner and the coresident child(ren). We therefore disregard whether the respondent also coresides with other relatives. This means, for example, that a nuclear family is assumed to be composed of a couple with common children, regardless of whether this couple lives in the same household with other relatives. ${ }^{5}$ Our definition of nuclear families does not take into consideration the marital status of the respondents, but we provide a

4 For a more detailed discussion on the problems related to the definition of stepfamilies, see Martin (2008).

5 This also requires that we disregard whether the children of the respondent already have their own children. There are a few cases in which this applies, as the sample includes respondents with children up to ages 18 . 
descriptive analysis which shows to what extent nuclear families are composed of married couples.

Childless respondents and the small group of respondents who only have adopted or foster children have been excluded from the sample. If a respondent has biological children and adopted or foster children, we consider his or her biological children, but disregard the adopted or foster children. As the share of adopted and foster children is extremely small, omitting these children from the analysis does not, however, cause any bias. We also omit the small group of respondents with incomplete information from the household grid. Altogether, the remaining sample contains 3,218 French, 2,533 western German, 539 eastern German and 4,030 Russian respondents. A western German respondent is here defined as a person who coresides in western Germany at the time of the interview while an eastern German respondent is defined as a person who lives in eastern Germany at the time of the interview. ${ }^{6}$ We analyze both parts of Germany separately as marital and fertility behavior between the two parts of Germany strongly differ (Goldstein and Kreyenfeld 2011). We are, however, unable to account for the fact that substantial migration has occurred since unification and that internal migration might blur a comparison of behavior in eastern and western Germany.

\section{Prevalence and socio-economic characteristics of stepfamilies}

\subsection{Prevalence of stepfamilies}

Table 2 tabulates the respondents by family type. The table supports previous findings regarding the prevalence of stepfamilies in France showing that they make up less than 10 percent of all families (Martin 1995). For the Russian Federation, we find a share of 13

6 We group West Berlin to eastern Germany. West Berlin used to belong to the Federal Republic of Germany before unification, but it is geographically located in the eastern parts of Germany. 
percent stepfamilies. For western Germany, we find the same percentages as for the Russian Federation. This result is surprising as we had expected that high Russian divorce rates would transfer into a high incidence of stepfamilies, while the traditional western German family behaviour would result into a low prevalence of this type of families.

The results for western Germany are in line with estimates reported by Steinbach (2008) with data from the German GGS. However, it needs to be mentioned that these findings are at odds with prior work on the same topic. The most comprehensive study which provided necessary information to generate the prevalence of stepfamilies was the German Youth Survey from the years 1994 and 2000 (Bien et al. 2002). Based on this data, Teubner (2002a: 40) estimated that stepfamilies make up only about five percent of all families with children under age 18 in western Germany (and eleven percent in the eastern part) which is substantially lower than the values that we have generated with the German GGS. Possibly, differences relate to the different time periods. It has also been mentioned that the German Youth Survey from the years 1994 and 2000 oversampled respondents in urban areas who are married and have children and private property which could also explain the discrepancy (Steinbach 2008: 166). However, we are unable to resolve this issue as we have no other external sources to validate these numbers due to the lack of information on stepfamilies in census and micro-census data.

For eastern Germany, our results suggest that stepfamilies are rather widespread as they compose 18 percent of all families. This is compatible with our idea that higher shares of nonmarital births and low marriage intensities transfer into a high prevalence of stepfamilies. It also fits to prior research on the topic which reports relatively high shares of stepfamilies in eastern than in western Germany (Teubner 2002a; Steinbach 2008). Studies based on data from the Family and Fertility Survey (FFS) also show that eastern Germany stands out in cross-national comparison with an extraordinarily high share of women who have children when they start coresiding with a partner (Prskawetz et al. 2003: 124). Also the estimates 
from this study need to be taken with some caution, though. This latter study used retrospective fertility and partnership histories from the FFS which do, however, not contain any detailed stepfamily episodes. For simplicity, it had been assumed that all children that had been born one year or more prior to the beginning of a cohabitation episode with the current partner were children from prior unions. This is, however, a strong assumption as it wrongly classifies families as stepfamilies who had their children while they lived apart and only moved together at later stages in their life courses. Therefore, it is unclear whether the finding from the FFS is indicative of a high prevalence of stepfamilies in eastern Germany, or whether it merely reflects the fact that the retrospective histories of the FFS covered the period when Germany was separated and the housing situation precluded young East German couples from moving in together. However, our analysis is based on a cross-section of family types for the year 2005 in which we have detailed information on the relationship status of all family members. Thus, our analysis does not suffer from the same problems and we may therefore conclude that stepfamilies are more prevalent in eastern than in western Germany.

The table also identifies stepfamilies according to whether they are stepmother families, stepfather families, stepmother-stepfather families or blended families. Blended families are further identified according to which of the two partners has children from a previous partnership. The table shows that the share of stepfather families is substantially higher than the share of stepmother families, which supports the assumption that the children tend to stay with their mothers after separation. The same is true if we look at blended families; here the share of blended-stepfather families is also high, indicating that the couple lives with common children and children of the woman from a previous partnership. Even though we observe a dominance of stepfather and blended-stepfather families for all countries, some country variations are discernable. In the Russian Federation, the share of stepmother families is particularly low, suggesting that it is very uncommon for children to stay with their fathers after the breakdown of a union. In France and the Russian Federation, the share of blended 
families is rather high while the opposite is true for eastern and western Germany which largely supports prior findings on the fertility in stepfamilies (Thomson 2004: 127).

Table 2: Respondents by family type, column percent

\begin{tabular}{|c|c|c|c|c|}
\hline & France & $\begin{array}{l}\text { Western } \\
\text { Germany }\end{array}$ & $\begin{array}{r}\text { Eastern } \\
\text { Germany }\end{array}$ & $\begin{array}{r}\text { Russian } \\
\text { Federation }\end{array}$ \\
\hline \multicolumn{5}{|l|}{ All families } \\
\hline Nuclear family & 81 & 77 & 68 & 74 \\
\hline Stepfamily & 9 & 13 & 18 & 13 \\
\hline Single parent & 10 & 10 & 14 & 13 \\
\hline Total & 100 & 100 & 100 & 100 \\
\hline Number of cases & 3,218 & 2,533 & 539 & 4,030 \\
\hline \multicolumn{5}{|l|}{ Stepfamilies } \\
\hline Stepfather family ${ }^{1)}$ & 33 & 43 & 49 & 44 \\
\hline Stepmother family ${ }^{2)}$ & 10 & 25 & $(24)$ & 6 \\
\hline Stepmother-stepfather ${ }^{3)}$ & (5) & (1) & (2) & (3) \\
\hline Blended stepfather family ${ }^{4}$ & 40 & 22 & (19) & 42 \\
\hline Blended stepmother family ${ }^{5)}$ & $(10)$ & (8) & (6) & (5) \\
\hline Blended stepmother-stepfather family ${ }^{6)}$ & (2) & $(0)$ & (0) & (1) \\
\hline Total & 100 & 100 & 100 & 100 \\
\hline Number of cases & 267 & 330 & 88 & 485 \\
\hline
\end{tabular}

Notes: The sample comprises respondents who have children age 18 and younger with whom they coreside.

Data have been weighted; () cells are composed of fewer than 30 respondents.

${ }^{1)}$ Stepfather family: A mother with her biological children and a stepfather; ${ }^{2)}$ Stepmother family: A father with his biological children and a stepmother; ${ }^{3)}$ Stepmother and stepfather family: A mother with her biological children and a father with his biological children ${ }^{4)}$ Blended stepfather family: A mother with her biological children and a stepfather + common children; ${ }^{5}$ Blended stepmother family: A father with his biological children and a stepmother + common children ${ }^{6}$ Blended stepmother and stepfather family: A mother with her biological children and a father and his biological children + common children

Source: GGS, wave 1 


\subsection{Socio-economic characteristics of stepfamilies and nuclear families}

We generally assume that stepfamilies are larger families. This is supported by Table 3, which shows the mean number of children by family type. This is true for all three of the countries under consideration. However, there are marked differences between the countries. Family size in France is much higher than in Germany or the Russian Federation, which fits the wellknown differences in completed fertility between the countries. What is also striking is that the relative differences between stepfamilies and nuclear families are greater in France. What is also noteworthy for France is that the number of non-resident stepchildren (i.e. the children of the partner of the respondent) is larger than in the two other countries. The same is true for the number of non-resident children of previous partners. Therefore, our previous conclusion that the share of stepfamilies is rather low in France must be attributed to our narrow definition of stepfamilies. When we consider the large family network, France stands out due to the high number of non-resident stepchildren in the country. The German stepfamily differs markedly from the French stepfamily as relatively few non-resident children are involved in stepfamilies in Germany.

Table 3: Number of children by family type

\begin{tabular}{|lrrrr|}
\hline & France & $\begin{array}{r}\text { Western } \\
\text { Germany }\end{array}$ & $\begin{array}{r}\text { Eastern } \\
\text { Germany }\end{array}$ & $\begin{array}{r}\text { Russian } \\
\text { Federation }\end{array}$ \\
\hline Nuclear family & & & & \\
Resident children of respondent \& partner & 1.93 & 1.90 & 1.65 & 1.59 \\
Non-resident children of respondent \& partner & 0.15 & 0.05 & 0.04 & 0.13 \\
Non-resident children of respondent & 0.07 & 0.03 & 0.07 & 0.05 \\
Non-resident children of partner & 0.08 & 0.03 & 0.03 & 0.08 \\
Total & 2.23 & 2.01 & 1.79 & 1.85 \\
Sample Size & 2,438 & 1,846 & 344 & 2,809 \\
\hline
\end{tabular}


Table 3 (continued): Number of children by family type

\begin{tabular}{|lcccc|}
\hline Stepfamily & & & & \\
Resident children of respondent \& partner & 0.74 & 0.43 & 0.36 & 0.56 \\
Resident children of respondent & 0.84 & 1.33 & 1.19 & 0.77 \\
Resident children of partner & 0.69 & 0.23 & 0.30 & 0.52 \\
Non-resident children of respondent \& partner & 0.03 & 0.04 & 0.00 & 0.02 \\
Non-resident children of respondent & 0.45 & 0.12 & 0.22 & 0.28 \\
Non-resident children of partner & 0.43 & 0.11 & 0.15 & 0.35 \\
Total & 3.19 & 2.25 & 2.22 & 2.49 \\
Sample Size & 267 & 330 & 88 & 485 \\
\hline
\end{tabular}

Notes: The sample comprises respondents who have children ages 18 and younger with whom they coreside. Lone parents have been excluded from this table. Data have been weighted.

Source: GGS wave 1

Table 4 compares the marital status of nuclear and stepfamilies at the time of the interview. We distinguish here between married, single, divorced and widowed respondents. As this table only considers respondents who coreside with their partners, the divorced, single and widowed respondents are in fact cohabitees. The table shows that marriage is the dominant arrangement in both step- and nuclear families. However, cohabitation (of a single, divorced or widowed woman) is more common in stepfamilies than in nuclear families. The country that stands out is, again, the Russian Federation where we find a large fraction of widowed and divorced respondents among the stepfamilies. But also in France, nuclear and stepfamilies differ significantly as the share of married respondents is quite low in the group of stepfamilies. Contrary to our expectations, we find that step- and nuclear families hardly differ in western Germany. For both groups, we find that more than 80 percent of the couples are married. This finding stands in some contrast to our predictions as we assumed that the social policy regulations (i.e. the maintenance payments to care-giving divorcees) could 
discourage re-marriage. The relatively low share of cohabitees among the stepfamilies contradicts this notion.

Table 4: Marital status of respondent by family type

\begin{tabular}{|lrrrr|}
\hline & France & $\begin{array}{r}\text { Western } \\
\text { Germany }\end{array}$ & $\begin{array}{r}\text { Eastern } \\
\text { Germany }\end{array}$ & $\begin{array}{r}\text { Russian } \\
\text { Federation }\end{array}$ \\
\hline Nuclear Family & & & & \\
Married & 78 & 94 & 78 & 93 \\
Single \& cohabiting & 21 & 6 & 21 & 6 \\
Divorced \& cohabiting & 1 & 0 & 1 & 1 \\
Widowed \& cohabiting & 0 & 0 & 0 & 0 \\
Total & 100 & 100 & 100 & 100 \\
Sample size & 2,438 & 1,846 & 334 & 2,809 \\
& & & & \\
Stepfamily & & & 60 & \\
Married & 44 & 83 & 26 & 18 \\
Single \& cohabiting & 31 & 10 & 13 & 26 \\
Divorced \& cohabiting & 22 & 5 & 1 & 5 \\
Widowed \& cohabiting & 3 & 1 & 100 & 100 \\
Total & 100 & 100 & 88 & 485 \\
Sample size & 267 & 330 & & \\
Nat The
\end{tabular}

Notes: The sample comprises respondents who have children ages 18 and younger with whom they coreside.

Lone parents have been excluded for this representation. Data have been weighted.

Source: GGS wave 1

Table 5 shows the trajectories that lead into stepfamily parenthood. In this table, stepfamilies are categorised according to the way the partnership prior to the current union ended. We distinguish here between widowhood, separation, divorce and singlehood. Respondents who were never in a coresidential union before they entered the stepfamily are classified as "never in a cohabiting union". Respondents whose last marital union ended in divorce are placed in the "divorce" category. "End of cohabiting union" includes respondents whose last union was a cohabiting union. "Widowhood" includes respondents whose former partners died, regardless of whether they lived together in a marital or non-marital union. For Germany, we 
are unfortunately unable to present estimates as they show unreasonably large shares of respondents who had no partnership before they entered a stepfamily. We attribute this to the poor quality of the partnership histories and we therefore refrain from displaying the results. For the other two countries, we find a plausible pattern that is in line with what we know about the demographic regimes in these two countries. In France, the breakdown of a cohabiting union is just as likely to be a precursor of stepfamily membership as the termination of a marital union. In the Russian Federation, divorce is a frequent track to stepfamily membership. However, what is very striking for the Russian Federation is the relatively large share of respondents who live in a stepfamily, and whose prior partnership ended because the partner had died. This obviously relates to the high mortality risks in the country.

Table 5: Trajectory into stepfamily membership. Respondents in stepfamilies distinguished by preceding partnership status

\begin{tabular}{|lcc|}
\hline & France & Russian Federation \\
\hline Never in cohabiting or marital union & 27 & 27 \\
Divorce & 34 & 44 \\
End of cohabiting union & 35 & 18 \\
Widowhood & 5 & 11 \\
Total & 100 & 100 \\
Sample size & 267 & 485 \\
\hline
\end{tabular}

Notes: The sample comprises respondents who have children ages 18 and younger with whom they coreside. For this representation, only stepfamilies have been selected.

Source: GGS wave 1 


\section{Economic conditions and family type}

\section{Dependent variable and method}

The following part of the analysis addresses the socio-economic well-being of different types of families. The key question here is whether stepfamilies fare worse economically than other families. The operational definition of the dependent variable is whether the respondent thinks that he/she can make ends meet financially. ${ }^{7}$ There are six answer categories given to the respondent: 1: with great difficulty, 2: with difficulty, 3: with some difficulty, 4: fairly easily, 5: easily and 6: very easily. As a method, we apply an ordered probit regression. Our modelling strategy is a stepwise inclusion of the socio-demographic covariates. This strategy allows us to investigate whether the differences in economic well-being between families can be explained by the different socio-demographic characteristics of stepfamilies and other types of families. Our sample includes both male and female respondents. It is likely that the socio-economic characteristics of the woman and the man have a different impact on the wellbeing of a household. This should particularly be true for a male breadwinner regime like Germany where the man's economic standing should primarily define the economic wellbeing of the family. For this reason, we also estimate another set of models where we distinguish between woman and man's level of education. We also account for the employment status by sex. As we were unable to construct these variables for single parent households, these families have been left out for this subset of the analyses. Also left out for this part of the analysis are same-sex unions. All analyses are conducted separately for France, Germany and the Russian Federation. As the eastern German sample is rather small, we grouped eastern and western Germany together for this part of the analysis. However, we

7 The wording in the core questionnaire of the GGS is as follows: "A household may have different sources of income and more than one household member may contribute to it. Thinking of your household's total monthly income, is your household able to make ends meet?" 
performed interaction models to test whether the relationship between family type and economic hardship differs between the two parts of Germany.

Figure 1 displays the mean values of the dependent variable by family type. The key variable is an ordinal variable where high numbers mean little economic hardship and low numbers mean greater economic difficulties. The figure shows that stepfamilies do worse than nuclear families in France and western Germany. The mean value in western Germany for stepfamilies is 3.6 , but it is 4.0 for nuclear families. For France, the respective figures are 3.2 (stepfamilies) and 3.4 (nuclear families). For the Russian Federation and eastern Germany, we do not observe much of a difference between step- and nuclear families. For all four regions, we observe that single parents are the most likely to report economic difficulties.

Figure 1: Economic difficulties by family type and region, mean values of the ordinal variable that indicates if the household is able to make ends meet (1: with great difficulty, 2: with difficulty, 3: with some difficulty, 4: fairly easily, 5: easily, 6: very easily)

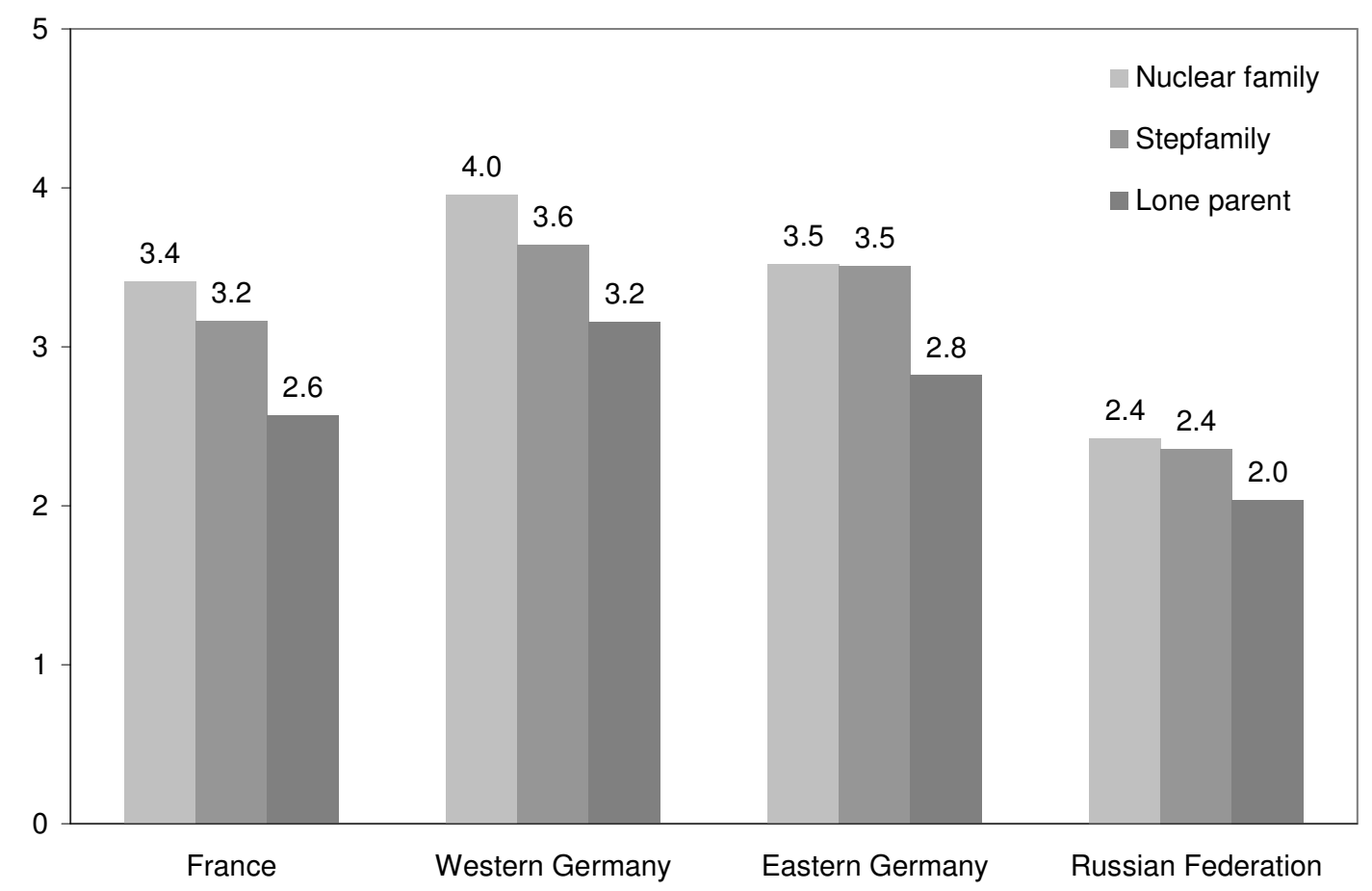

Notes: The sample comprises respondents who have children ages 18 and younger with whom they coreside. Source: GGS wave 1 


\section{Independent variables and composition of the sample}

Table 6 displays the composition of the sample by family status and country. We accounted for standard socio-demographic variables, such as citizenship, age, education, employment status, age of the youngest resident child and the number of non-resident and resident children. The table also reports the sex composition of the sample showing that the large share of single parents are single mothers.

The variable "citizenship" distinguishes respondents with the citizenship of the country of interview from other respondents. For Germany, we also noted whether the interview was conducted in eastern or western Germany. As in the descriptive analysis, Berlin was grouped into eastern Germany. For the Russian Federation, we used a flag variable in the model that indicating whether the interview was conducted in Saint Petersburg or Moscow to account for the low response rate in these cities.

Education was constructed by drawing on the ISCED-97-classification. We grouped the ISCED levels 0-2 into the category "low education", 3-4 into the category "medium education" and 5-6 into the category "high education". We should point out that the distribution of the educational variable is quite different in each of the countries. In France, we observe a much higher share of respondents with a high level of education. This can be attributed to the fact that we treated respondents with a baccalauréat, which is a standard track in the educational career in France, as ISCED 5. If one turns to the bivariate relationship between education and family type, there is a clear correlation between stepfamily membership and educational attainment in France. Respondents who live in stepfamilies are less educated. We also find a similar correlation for the Russian Federation and Germany, but the association is less strong than for France. Apart from individual education, we have also generated variables that indicate the level of education of the female and male person in the household. 
We integrated employment status into the analysis by distinguishing between respondents who are employed, unemployed, not working and others. The category "not working" includes the category "looking after the home or family" as well as maternity and parental leave. We also generated this variable for the female and male in the household. The descriptive statistics for these latter variables show that Russian women are more likely to be employed than women in the other two countries. Employment rates in France are also higher than in Germany. Overall, we do not see much difference in the employment status by family type in the three countries. However, French stepfamilies seem to be at extraordinarily high risks of unemployment compared to nuclear families.

In order to account for the number of children, we include two variables. One variable indicates the number of resident children. The other variable indicates the number of nonresident children. Both are treated as continuous variables. As was mentioned in the previous section, the family sizes of nuclear families and of stepfamilies differ. The difference is largest in France, where a stepfamily has on average 0.9 non-resident children. Hardly any of the single parents in our sample have non-resident children. Because the type of family is closely correlated with the number of children, our independent variables are, unfortunately, collinear. We checked, however, whether our results remain robust if we restrict the analysis to nuclear and stepfamilies. As they are, we decided to keep lone parents in the sample.

Age was entered as a continuous variable. In addition, age was considered as a squared term (multiplied by 100) to account for nonlinearities. We also accounted for the age of the youngest child by a continuous variable. Due to the low age at childbearing, the respondents in the Russian sample are younger than the respondents in the German or French samples. 
Table 6: Descriptive statistics, column \% (categorical variables), mean (continuous variables)

\begin{tabular}{|c|c|c|c|c|c|c|c|c|c|}
\hline & \multicolumn{3}{|l|}{ France } & \multicolumn{3}{|c|}{ Germany } & \multicolumn{3}{|c|}{ Russian Federation } \\
\hline & Nucl. & Step & Lone & Nucl. & Step & Lone & Nucl. & Step & Lone \\
\hline Economic difficulty & 7 & 13 & 26 & 3 & 5 & 12 & 23 & 27 & 41 \\
\hline Difficulty & 17 & 18 & 22 & 9 & 12 & 21 & 26 & 25 & 24 \\
\hline Some difficulty & 26 & 27 & 27 & 23 & 29 & 30 & 40 & 38 & 27 \\
\hline Fairly easily & 31 & 26 & 20 & 35 & 31 & 25 & 8 & 8 & 5 \\
\hline Easily & 16 & 15 & 5 & 23 & 19 & 10 & 3 & 2 & 2 \\
\hline Very easily & 3 & 2 & 1 & 7 & 5 & 3 & 0 & 0 & 1 \\
\hline Sex of respondent & & & & & & & & & \\
\hline Male & 45 & 48 & 15 & 40 & 36 & 12 & 43 & 44 & 5 \\
\hline Female & 55 & 52 & 85 & 60 & 64 & 88 & 57 & 56 & 95 \\
\hline Citizenship respondent & & & & & & & & & \\
\hline Native & 87 & 89 & 86 & 81 & 83 & 87 & 89 & 90 & 90 \\
\hline Other citizenship & 13 & 11 & 14 & 19 & 17 & 13 & 11 & 10 & 10 \\
\hline Region & & & & & & & & & \\
\hline Eastern Germany & - & - & - & 15 & 21 & 25 & - & - & - \\
\hline Moscow/ St. Petersb. & - & - & - & - & - & - & 11 & 14 & 14 \\
\hline Education respondent & & & & & & & & & \\
\hline Low & 20 & 29 & 31 & 10 & 12 & 20 & 5 & 7 & 5 \\
\hline Medium & 12 & 9 & 15 & 59 & 62 & 55 & 71 & 76 & 71 \\
\hline High & 68 & 62 & 54 & 29 & 25 & 21 & 24 & 16 & 25 \\
\hline Unknown & 0 & 0 & 0 & 2 & 1 & 4 & 0 & 0 & 0 \\
\hline Education female in hh. & & & & & & & & & \\
\hline Low & 20 & 29 & 31 & 13 & 14 & 21 & 6 & 9 & 5 \\
\hline Medium & 15 & 12 & 15 & 62 & 64 & 54 & 69 & 73 & 71 \\
\hline High & 65 & 58 & 53 & 23 & 20 & 21 & 25 & 16 & 24 \\
\hline Unknown & 0 & 1 & 0 & 2 & 2 & 3 & 0 & 1 & 0 \\
\hline Education male in hh. & & & & & & & & & \\
\hline Low & 19 & 25 & 28 & 6 & 10 & 11 & 5 & 8 & 0 \\
\hline Medium & 9 & 8 & 13 & 56 & 57 & 64 & 72 & 76 & 70 \\
\hline High & 71 & 66 & 59 & 37 & 31 & 21 & 23 & 15 & 30 \\
\hline Unknown & 0 & 1 & 0 & 1 & 2 & 4 & 0 & 0 & 0 \\
\hline Employment respondent & & & & & & & & & \\
\hline Employed & 78 & 75 & 69 & 68 & 66 & 56 & 73 & 71 & 76 \\
\hline Unemployed & 6 & 12 & 17 & 6 & 8 & 19 & 7 & 8 & 7 \\
\hline Not working & 12 & 10 & 9 & 23 & 22 & 19 & 15 & 16 & 10 \\
\hline Other & 4 & 3 & 5 & 3 & 4 & 7 & 5 & 6 & 7 \\
\hline Employment female & & & & & & & & & \\
\hline Employed & 69 & 64 & 66 & 52 & 56 & 54 & 65 & 61 & 76 \\
\hline Unemployed & 6 & 9 & 19 & 5 & 6 & 19 & 6 & 8 & 6 \\
\hline Not working & 21 & 22 & 11 & 40 & 35 & 21 & 25 & 26 & 11 \\
\hline Other & 3 & 4 & 5 & 3 & 3 & 6 & 4 & 6 & 7 \\
\hline Employment male & & & & & & & & & \\
\hline Employed & 91 & 85 & 86 & 89 & 87 & 68 & 85 & 84 & 78 \\
\hline Unemployed/ not work. & 5 & 11 & 6 & 7 & 9 & 20 & 9 & 8 & 10 \\
\hline Other & 4 & 3 & 8 & 4 & 5 & 13 & 6 & 8 & 13 \\
\hline Continuous variables & & & & & & & & & \\
\hline \# resident children & 2.0 & 2.3 & 1.7 & 1.9 & 2.0 & 1.7 & 1.5 & 1.8 & 1.4 \\
\hline \# non-resident children & 0.3 & 0.9 & 0.0 & 0.1 & 0.3 & 0.2 & 0.3 & 0.7 & 0.0 \\
\hline Age of youngest child & 6.7 & 7.3 & 8.9 & 7.6 & 8.5 & 9.3 & 9.0 & 8.7 & 10.7 \\
\hline Age & 38.9 & 39.4 & 39.7 & 39.2 & 39.5 & 38.4 & 36.5 & 36.2 & 37.9 \\
\hline Number of cases & 2,438 & 267 & 513 & 2,180 & 418 & 474 & 2,809 & 485 & 736 \\
\hline
\end{tabular}

Note: The sample only comprises respondents who live with their children ages 18 or younger in the same household.

Source: GGS wave 1 


\section{Results of multivariate model}

Table 7 displays the results from the ordered probit model that investigates the determinants of economic hardship for women with children. We have estimated separate models for the three countries. For each country, we have again estimated three regressions. The first regression only contains our key variable of interest — namely, the family type — as well as standard control variables, such as citizenship, age and the age of the youngest child. Model 2 also controls for education and employment status and the final model includes the number of resident and non-resident children. We followed this stepwise inclusion of variables in order to check whether differences in economic well-being between step- and nuclear families can be explained by the special socio-economic composition of the group of stepfamilies.

Turning first to the models for France, we find that the first model, which only contains the major controls (M1), shows that stepfamilies more often experience greater economic hardship than nuclear families. Worse off are single parents who perform significantly worse than nuclear families. The control variables are mostly in line with general expectations: foreigners as well as younger women experience economic difficulties more often than others. The results for education and employment status, which are included in Model 2, are also very much in line with general expectations. Low education and unemployment are strongly associated with economic difficulties. Model 3 shows that the number of resident and nonresident children increases economic difficulties significantly. The most important finding of this stepwise analysis is, however, that the coefficient for being a member of a stepfamily becomes weak after controlling for education and employment and becomes insignificant after the number of children has been included into the model. In the final model (M 3), we no longer find any statistical differences between step- and nuclear families. From this, we can conclude that differences in economic well-being between step- and nuclear families in 
France can be completely explained by compositional differences between the two comparison groups.

For Germany, we find that non-German citizenship strongly increases economic difficulties, as do non-employment and low education. What is special about Germany is that economic well-being differs between stepfamilies and nuclear families, and that these differences remain after controlling for the number of children. For the Russian Federation, the results are at odds with the French pattern: women in stepfamilies and in nuclear families do not differ with respect to economic difficulties. This holds true before and after controlling for education, employment and the number of children. For the Russian Federation, the dividing line in economic well-being only runs between lone parents and other types of families. Other covariates, such as education, the age of the youngest child and employment status, are similar. What is striking for the Russian Federation is, however, that older respondents suffer greater difficulties than younger ones.

Table 8 is finally limited to respondents in partnerships and thus, to stepfamilies and nuclear families. This table distinguishes the impact of female and male education and employment. The analysis shows that high education of both men and women lowers economic hardship. It also shows that male non-employment has a very strong negative impact on the economic well-being of the household. Female unemployment also negatively affects the economic well-being of the household. This is, however, not the case for female non-employment (including maternity leave, parental leave and "looking after the home or family") which only moderately relates to economic distress. The most important finding from this table is, however, that the previous results are buttressed. Stepfamilies do worse in Germany, even after controlling for the socio-economic composition of the sample. This is not the case for the two other countries.

We also investigated whether the association between family type and economic well-being differs between eastern and western Germany. For this reason, we ran a model in which we 
interacted family type with region (see Table 8, Model 2 for Germany). In line with the previous analysis, we find that stepfamilies are disadvantaged in terms of economic wellbeing in western Germany. For eastern Germany, we do not find the same association. Here, we find that the coefficient for stepfamilies is insignificant and close to zero indicating that stepfamilies do not differ from nuclear families.

Table 7: Ordered probit model, dependent variable indicates if household is able to make ends meet (1: with great difficulty, 2: with difficulty, 3: with some difficulty, 4: fairly easily, 5: easily, 6: very easily)

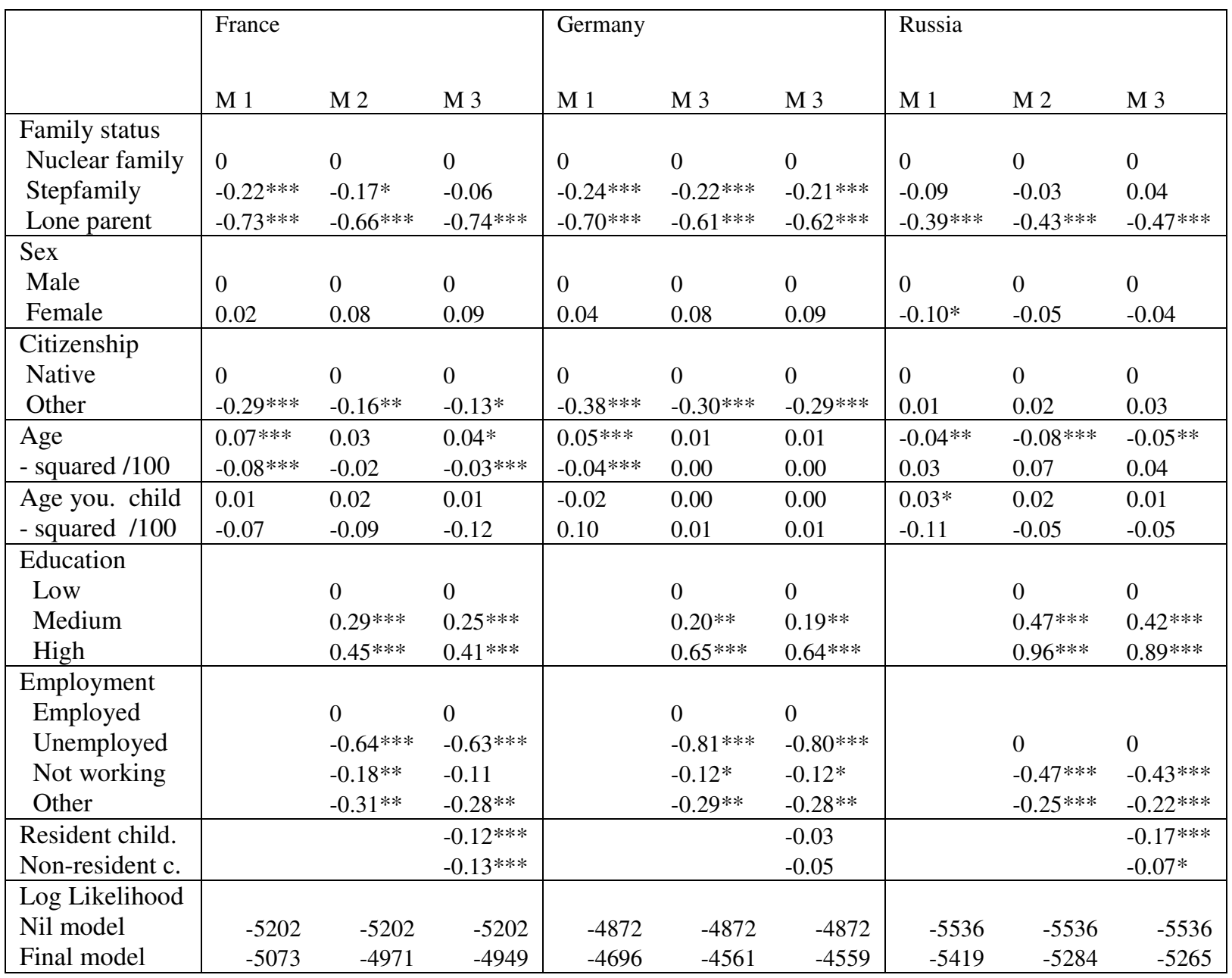

Note: $* \mathrm{p}<0.05 ; * * \mathrm{p}<0.01 ; * * * \mathrm{p}<0.001$.

The sample comprises respondents who live with their children ages 18 or younger in the same household. The constant terms are not shown in the table. The regression for the Russian Federation also controls for whether the interview was conducted in Moscow or Saint Petersburg. The regression for Germany also controls for whether the respondent lived in eastern or western Germany. In a addition, a dummy for missing education was employed.

Source: GGS wave 1 
Table 8: Ordered probit model, dependent variable indicates if household is able to make ends meet, only respondents with partners (1: with great difficulty, 2: with difficulty, 3: with some difficulty, 4: fairly easily, 5: easily, 6: very easily)

\begin{tabular}{|c|c|c|c|c|}
\hline & $\begin{array}{l}\text { France } \\
\text { M1 } \\
\end{array}$ & M1 & $\begin{array}{l}\text { many } \\
\text { M2 }\end{array}$ & $\begin{array}{l}\text { Russian Federation } \\
\text { M1 }\end{array}$ \\
\hline $\begin{array}{l}\text { Family status } \\
\text { Nuclear family } \\
\text { Stepfamily }\end{array}$ & $\begin{array}{l}0 \\
0.07\end{array}$ & $\begin{array}{l}0 \\
-0.22 * * *\end{array}$ & & $\begin{array}{l}0 \\
0.06\end{array}$ \\
\hline $\begin{array}{l}\text { Family status } \\
\text { Nuclear family (western Germany) } \\
\text { Stepfamily (western Germany) } \\
\text { Nuclear family (eastern Germany) } \\
\text { Stepfamily (eastern Germany) }\end{array}$ & & & $\begin{array}{l}0.25 * * * \\
-0.01 \\
0 \\
0.002\end{array}$ & \\
\hline $\begin{array}{l}\text { Education female } \\
\text { Low } \\
\text { Medium } \\
\text { High }\end{array}$ & $\begin{array}{l}0 \\
0.45 * * * \\
0.69 * * *\end{array}$ & $\begin{array}{l}0 \\
0.17 * \\
0.44 * * *\end{array}$ & $\begin{array}{l}0 \\
0.17 * \\
0.44 * * *\end{array}$ & $\begin{array}{l}0 \\
0.45 * * * \\
0.69 * * *\end{array}$ \\
\hline $\begin{array}{l}\text { Education male } \\
\text { Low } \\
\text { Medium } \\
\text { High } \\
\end{array}$ & $\begin{array}{l}0 \\
-0.05 \\
0.42 * * * \\
\end{array}$ & $\begin{array}{l}0 \\
0.14 \\
0.57 * * *\end{array}$ & $\begin{array}{l}0 \\
0.14 \\
0.57 * * *\end{array}$ & $\begin{array}{l}0 \\
-0.05 \\
0.39 * * * \\
\end{array}$ \\
\hline $\begin{array}{l}\text { Employment status female } \\
\text { Employed } \\
\text { Unemployed } \\
\text { Not working/ leave } \\
\text { Other }\end{array}$ & $\begin{array}{l}0 \\
-0.38 * * * \\
-0.17 * * \\
-0.04 \\
\end{array}$ & $\begin{array}{l}0 \\
0.67 * * * \\
-0.13 * * \\
-0.01\end{array}$ & $\begin{array}{l}0 \\
0.68 * * * \\
-0.13 * * \\
-0.01 \\
\end{array}$ & $\begin{array}{l}0 \\
-0.37 * * * \\
-0.18 * * * \\
-0.04 \\
\end{array}$ \\
\hline $\begin{array}{l}\text { Employment status male } \\
\text { Employed } \\
\text { Unemployed/ not working } \\
\text { Other }\end{array}$ & $\begin{array}{l}0 \\
-0.49 * * * \\
-0.12 \\
\end{array}$ & $\begin{array}{l}0 \\
-0.81 * * * \\
-0.32 * *\end{array}$ & $\begin{array}{l}0 \\
-0.81 * * * \\
-0.31 * *\end{array}$ & $\begin{array}{l}0 \\
-0.48 * * * \\
-0.11\end{array}$ \\
\hline $\begin{array}{l}\text { Log Likelihood } \\
\text { Nil model } \\
\text { Final model }\end{array}$ & $\begin{array}{l}-4517 \\
-4280\end{array}$ & $\begin{array}{l}-4027 \\
-3740\end{array}$ & $\begin{array}{l}-4027 \\
-3738\end{array}$ & $\begin{array}{l}-4516 \\
-4268\end{array}$ \\
\hline
\end{tabular}

Note: $* \mathrm{p}<0.05 ; * * \mathrm{p}<0.01 ; * * * \mathrm{p}<0.001$.

The sample comprises respondents who live with their children ages 18 or younger in the same household. The constant terms are not shown in the table. The regression for the Russian Federation also controls for whether the interview was conducted in Moscow or Saint Petersburg. The regression for Germany also controls for whether the respondent lived in eastern or western Germany. In addition, a dummy for missing education was employed. Other variables in the model are citizenship, age, age squared, age of youngest child, age of youngest child squared, number of resident and non-resident children.

Source: German GGS wave 1 


\section{Summary and conclusion}

The aim of this paper was to study the economic well-being of stepfamilies in France, Germany and the Russian Federation using data from the first wave of the Generations and Gender Survey. As was done in previous studies, we limited the sample to respondents with at least one coresiding step- or biological child under age 18. We have also adhered to the standard definition, according to which a family qualifies as being a stepfamily if one of the coresiding children is from a prior partnership. Following this definition, our analysis has shown that the prevalence of stepfamilies is lowest in France, where about nine percent of all families can be classified as stepfamilies. In the Russian Federation and western Germany, the shares of stepfamilies are 13 percent, respectively. The prevalence of stepfamilies is highest in eastern Germany, at 18 percent.

Regarding the trajectory into stepfamily membership, the Russian case is remarkable for a modern society as an unusually large share (11 percent) of the respondents who live in a stepfamily were widowed before they entered the union. The analyses for France support the assumption that it is not just divorce, but also the breakdown of a non-marital union that commonly precedes entry into a stepfamily.

In addition to giving an account on the trajectories that lead into stepfamily membership, we also compared the marital status of stepfamilies and nuclear families at time of interview. Here we find again that the Russian Federation stands out with its high share of divorcees and widowed respondents among the stepfamilies. However, unmarried cohabitation is also relatively common in the French and eastern German stepfamily. In western Germany, respondents in step- and nuclear families are mostly married. This finding is at odds with our idea that social policy regulations (i.e. the maintenance regulations) would discourage western 
German women from re-marrying. Overall, our descriptive analyses on the prevalence of stepfamilies did not support well our presumptions. The prevalence of stepfamilies does not correlate well with other indicators of demographic change. Apparently, a high divorce rate, as we find it for the Russian Federation, does not necessarily transfer into a high prevalence of stepfamilies. On the other hand, we find high shares of stepfamilies in western Germany where marriage rates are relatively high and divorce rates at an only medium level. The French and the eastern German case show that high shares of non-marital births are compatible with both low and high shares of stepfamilies.

Regarding the socio-demographic composition of stepfamilies, we find that family size is larger in step- than in nuclear families. France is striking in this context as stepfamilies in this country are found to have a much larger number of children. The share of blended families is also particularly high in France. In respect to other socio-demographic indicators, there is no homogenous pattern. In France, we find that stepfamilies stick out as they are more often subject to unemployment than other families. We also find that stepfamily membership is often associated with somewhat lower education in France. In the Russian Federation and Germany, stepfamily members are also somewhat less educated than members of nuclear families. But the differences between these two family types are much smaller than in France.

Our investigation of the economic well-being of families reveals that stepfamilies differ from other families in France and in western Germany, but not in the Russian Federation and eastern Germany. In France, the socio-economic characteristics of stepfamilies, particularly the fact that these are larger families, explain why these families fare worse economically than other families. In western Germany, differences between nuclear and stepfamilies remain after controlling for socio-economic characteristics. In the Russian Federation and eastern Germany, stepfamilies do not differ significantly from other families. In these regions, the dividing line runs between single parents and other families. 
Our analysis provided an overview on the prevalence and economic conditions of stepfamilies in three of the largest countries in Europe using recent data. Unfortunately, our analyses also had to leave a lot of questions unresolved. One issue concerns the definition of stepfamilies. When we defined a stepfamily, we took into account the household context only. However, French respondents who live in stepfamilies have more non-resident stepchildren than respondents in stepfamilies in other countries. This means that our results must be viewed with caution as a wider definition which also includes relationships with non-resident children would probably lead to a completely different country ranking. Another problem with our analysis is that we had to handle the German analysis with great care as the retrospective partnership histories are biased in the German data. This precluded us from analysing the trajectories that lead into stepfamily membership in this country. Finally, the analyses of the economic situation of different types of families leave some issues unresolved. For France, we were able to explain the differences between families by citing the special socio-economic composition of the French stepfamily. However, for western Germany, we were unable to give a conclusive answer as to why stepfamilies do worse than other families. We discussed the particular social policy regulations in Germany which used to provide quite generous maintenance payments to divorcees. These special regulations could affect the well-being of stepfamilies if the male partner needs to pay maintenance to the ex-spouse. An argument that speaks for this interpretation is that we do not find differences between step- and nuclear families for eastern Germany for which these payments only play an inferior role. Germany has recently reformed maintenance regulations by curtailing the maintenance payments for divorcees. It remains to be seen whether this policy reform had any bearings on the relative economic performance of stepfamilies in this country. 


\section{Acknowledgment}

We thank our colleagues at the Max Planck Institute for Demographic Research and at the German Youth Institute for their valuable comments on an earlier version of the paper. In particularly we thank Sonja Bastin and Anne Hornung for detailed comments. We also would like to thank Miriam Hills for the language editing of the paper. 


\section{References}

Andrev, Evgueni M.; Hoffmann, Rasmus; Carlson, Elwood; Shkolnikov, Vladimir M.; Kharkova, Tatiana L. (2009): Concentration of working-age male mortality among manual workers in urban Latvia and Russia, 1970-1989. European Societies 11: 161-185.

Bien, Walter; Hartl, Angela; Teubner, Markus (2002): Stieffamilien in Deutschland. Eltern und Kinder zwischen Normalität und Konflikt. Opladen: Leske und Budrich.

Bradshaw, Jonathan; Kennedy, Steven; Kilkey, Majella; Hutton, Sandra; Corden, Anne; Eardley, Tony; Holmes, Hilary; Neale, Joana (1996): The Employment of Lone Parents: A Comparison of Policy in 20 Countries. London: Family Policy Studies Centre.

Buber, Isabella; Prskawetz, Alexia (2000): Fertility in second unions in Austria: Findings from the Austrian FFS. Demographic Research 3: 1-44.

Bumpass, Larry L.; Raley, Kelly R.; Sweet, James A. (1995): The changing character of stepfamilies: Implications of cohabitation and nonmarital Childbearing. Demography 32: 425436.

Cherlin, Andrew (1978): Remarriage as an incomplete institution. American Journal of Sociology 84: 634-650.

Cherlin, Andrew; Furstenberg, Frank F. (1994): Stepfamilies in the United States: A reconsideration. Annual Review of Sociology 20: 359-381.

Coontz, Stephanie (2000): The Way We Never Were. 2nd edition. New York: Basic Books.

Council of Europe (2005): Recent Demographic Developments in Europe, Strasbourg, Council of Europe. 
Desrosiers, Hélène; Le Bourdais, Céline; Laplante, Benoit (1995): Les dissolutions d'union dans les familles recomposées: l'expérience des femmes canadiennes. Recherches Sociographiques XXXVI: 47-64.

Dorbritz, Jürgen (2007): Rückgang der Scheidungsintensität in den Jahren 2005 und 2006. BiB-Mitteilungen 28: 13-16.

Esping-Andersen, Gøsta (1999): Social Foundations of Postindustrial Economies. Oxford: Oxford University Press.

Esping-Andersen, Gøsta (2009): The Incomplete Revolution. Adapting Welfare States to Women's New Roles. Cambridge: Polity Press.

Eurostat (2011): Nichtehelich Lebendgeborene. Tables, Graphs and Maps Interface. http://epp.eurostat.ec.europa.eu/tgm/table.do?tab=table\&init=1\&plugin=1\&language=de $\&$ pco $\underline{\mathrm{de}=}=\mathrm{tps} 00018$

Feldhaus, Michael; Huinink, Johannes (2011): Multiple Elternschaft. Eine Analyse zur Vielfalt von Elternschaft und Folgepartnerschaften. Zeitschrift für Familienforschung (forthcoming).

Festy, Patrick (1980): On the new context of marriage in Western Europe. Population and Development Review 6: 311-315.

Gauthier, Anne H. (2007): The impact of family policies on fertility in industrialized countries: A review of the literature. Population Research Policy Review 26: 323-346.

Generations and Gender Programme (2011): Generations and Gender Contextual Database. Netherlands Interdisciplinary Demographic Institute (distributor). Retrieved from: www.ggp-i.org/contextual-database.html on 10/06/2011.

Glick, Paul (1989): Remarried families, stepfamilies and stepchildren: A brief demographic profile. Family Relations 38: 24-27. 
Goldstein, Joshua R.; Kreyenfeld, Michaela (2011): East Germany overtakes West Germany: Recent trends in order-specific fertility dynamics. Population and Development Review (forthcoming).

Henz, Ursula; Thomson, Elizabeth (2005): Union stability and stepfamily fertility in Austria, Finland, France \& West Germany. European Journal of Population 21: 3-29.

Holland, Jennifer A.; Thomson, Elizabeth (2011): Stepfamily childbearing in Sweden: Quantum and tempo effects, 1950-99. Population Studies 65: 115-128.

Human Fertility Data Base (HFD) (2011): Human Fertility Database. Max Planck Institute for Demographic Research (http://www.humanfertility.org/)

Juby, Heather (2003-2004): Yours, mines, ours: New boundaries for the modern stepfamily. Transition Magazine. Ottawa: Vanier Institute of the Family 33: 3-6.

Juby, Heather; Marcil-Gratton, Nicole; Le Boudais, Céline (2001): A step further in family life: The emergence of the blended family. In: Bélanger, Alain: Report on the Demographic Situation in Canada 2000: 169-203. Ottawa: Statistics Canada. Cat. n 91-209.

Kanji, Shireen (2004): The route matters: Poverty and inequality among lone-mother households in Russia. Feminist Economics 10: 207-225.

Konietzka, Dirk; Kreyenfeld, Michaela (2002): Women's Employment and Non-Marital Childbearing: A Comparison between East and West Germany in the 1990s. Population - E 57 (2): $331-357$.

Köppen, Katja (2011): Marriage and Cohabitation in Western Germany and France. Dissertation. University of Rostock.

Kosolapov, Mikhail; Zakharov, Sergej (2005): The Report on Response Rate in Russian GGS. Demoscope. 
Kreyenfeld, Michaela; Hornung, Anne; Kubisch, Karolin; Jaschinski, Ina (2010): Fertility and union histories from German GGS data: Some critical reflections. MPIDR Working Paper 2010-23.

Kreyenfeld, Michaela; Konietzka, Dirk; Walke, Rainer (2011): Dynamik und Determinanten nichtehelicher Mutterschaft in Ost- und Westdeutschland. In: Brüderl, Josef; Castiglioni, Laura (eds.): Partnerschaft, Fertilität und intergenerationale Beziehungen: Ergebnisse der ersten Welle des Beziehungs- und Familienpanels. Schriften zum Beziehungs- und Familienentwicklungspanel, Band 3. Würzburg: Ergon Verlag (forthcoming).

Leon, David A.; Shkolnikov, Vladimir; McKee, Martin (2009): Alcohol and Russian mortality: a continuing crisis. Addiction 104: 1630-1636.

Lewis, Jane (1992): Gender and the development of welfare regimes. Journal of European Social Policy 2: 159-173.

Lokshin, Michael; Popkin, Marry, M; Mullan Harris, Kathleen (2000): Single mothers in Russia: Household strategies for coping with poverty. World Development 28: 2183-2198. Available at SSRN: http://ssrn.com/abstract=252834.

Marcil-Gratton, Nicole; Le Bourdais, Céline; Lapierre-Adamcyk, Évelyne (2000): The implications of parents' conjugal histories for children. ISUMA-Canadian Journal of Policy Research 1: 32-40.

Martin, Claude (1995): Father, mother and the welfare state - Family and social transfers after marital breakdown. Journal of European Social Policy 5: 43-63.

Martin, Valerie (2008): Stepfamilies in Canada: Numbers, Characteristics, Stability and Childbearing. Dissertation. Montreal: McGill University. 
Martin, Valerie; Le Bourdais, Céline (2008): Stepfamilies in Canada and Germany, a comparison. In: Bien, Walter; Marbach, Jan H. (eds.): Familiale Beziehungen. Familienalltag und soziale Netzwerke. Wiesbaden: Verlag für Sozialwissenschaften: 242-278.

Muszynska, Magdalena (2006): Woman's employment and union disruption in a changing socio-economic context: the case of Russia. MPIDR Working Paper 2006-027.

Naderi, Robert; Dorbritz, Jürgen; Ruckdeschel, Kerstin (2009): Der Generations and Gender Survey in Deutschland: Zielsetzung, Verortung, Einschränkungen und Potenziale. Zeitschrift für Bevölkerungsforschung 34: 5-30.

Nave-Herz, Rosemarie (1998): Die These über den ,Zerfall der Familie‘. In: Friedrichs, J. et al. (eds.): Die Diagnosefähigkeit der Soziologie. Kölner Zeitschrift für Soziologie und Sozialpsychologie. Sonderheft 38: 286-315.

Orloff, Ann Shola (1993): Gender and the social rights of citizenship: The comparative analysis of gender relations and welfare states. American Sociological Review 58: 303-328.

Orloff, Ann Shola (2009): Gendering the comparative analysis of welfare states: An unfinished agenda. Sociological Theory 27(3): 317-343.

Ostner, Ilona (1995): Arm ohne Ehemann? Sozialpolitische Regulierung von Lebenschancen für Frauen im internationalen Vergleich. Aus Politik und Zeitgeschichte B36-37:3-12.

Pascall, Gillian; Manning, Nick (2000): Gender and social policy: comparing welfare states in Central and Eastern Europe and the former Soviet Union. Journal of European Social Policy 10: $240-266$.

Perelli-Harris, Brienna; Gerber, Theodore P.: (2010): Non-marital childbearing in Russia: second demographic transition or pattern of disadvantage? Demography 47 (forthcoming). 
Perelli-Harris, Brienna; Sanchez Gassen, Nora E.: (2010): The reciprocal relationship between the state and union formation across Western Europe: policy dimensions and theoretical considerations. MPIDR Working Paper WP-2010-034.

Perelli-Harris, Brienna; Sigle-Rushton, Wendy; Kreyenfeld, Michaela; Lappppegård, Trude; Keizer, Renske; Berghammmmer. Caroline (2010): The educational gradient of childbearing within cohabitation in Europe. Population and Development Review 36(4): 775-801.

Prskawetz, Alexia; Vikat, Andres; Philipov, Dimiter; Engelhardt, Henriette (2003) : Pathways to stepfamily formation in Europe: Results from the FFS. Demographic Research 8: 107-149.

Saint-Jacques, Marie-Christine (1998): L'Ajustement des Adolescents et des Adolescentes dans les Familles Recomposées. Dissertation. Québec: Université Laval. Centre de Recherche sur les Services Communautaires.

Spielauer, Martin; Koytcheva, Elena; Kostova, Dora (2007): First and second birth in first and second union: a decomposition of fertility decline in Bulgaria and Russia since the 1989 economic and political transition. MPIDR Working Paper 2007-001.

Statistisches Bundesamt (2001): Bevölkerung und Erwerbstätigkeit: Gebiet und Bevölkerung 1999, Fachserie 1.1. Stuttgart: Metzler-Poeschel.

Steinbach, Anja (2008): Stieffamilien in Deutschland. Ergebnisse des Generations and Gender Survey 2005. Zeitschrift für Bevölkerungswissenschaft 33: 153-180.

Stewart, Susan D. (2007): Brave New Stepfamilies: Diverse Paths Toward Stepfamily Living. Thousand Oaks, Sage Publications.

Teubner, Markus (2002a): Wie viele Stieffamilien gibt es in Deutschland? In: Bien, Walter; Hartl, Angela; Teubner, Markus (eds.): Stieffamilien in Deutschland. Eltern und Kinder zwischen Normalität und Konflik: Opladen: Leske und Budrich: 23-50. 
Teubner, Markus (2002b): Die wirtschaftliche Lage von Stieffamilien. In: Bien, Walter; Hartl, Angela; Teubner, Markus (eds.): Stieffamilien in Deutschland. Eltern und Kinder zwischen Normalität und Konflik: Opladen: Leske und Budrich: 85-97.

Thomson, Elizabeth (2004): Stepfamilies and childbearing desires in Europe. Demographic Research 3: 116-134.

Vikat, Andres; Thomson, Elizabeth; Prskawetz, Alexia (2004): Childbearing responsibility and stepfamily fertility in Finland and Austria. European Journal of Population 20: 1-21.

Villeneuve-Gokalp, Catherine (2000): The double families of children of separated parents. Population (English Selection) 12: 111-137.

White, Lynn K.; Booth, Alan (1985): The quality and stability of remarriages: The role of stepchildren. American Sociological Review 50: 689-698.

Wu, Zheng; Schimmele, Christoph M. (2005): Repartnering after first union sisruption. Journal of Marriage and Family 67 (1): 27-36.

Zabel, Cordula (2008): Patterns of partnership formation among lone mothers in Russia. MPIDR Working Paper2008-20. 